\title{
Adiponectin levels in people with Latent Autoimmune Diabetes-a case control study
}

\author{
Sinead Brophy ${ }^{1 *}$, Helen Davies², Jeffrey W Stephens², Sarah L Prior², Mark Atkinson², Stephen Bain², Rhys Williams²
}

\begin{abstract}
Background: To examine adiponectin levels in people with Latent Autoimmune Diabetes in Adults using a matched pair case control study.

Findings: Patients with LADA $(n=64)$, were matched for sex with type 2 diabetic and non-diabetic controls. A matched paired T-test was used to examine average adiponectin levels in the LADA patients' versus controls. The average adiponectin level for the LADA patients was $9.96 \mu \mathrm{g} / \mathrm{ml}$ compared to $6.4 \mu \mathrm{g} / \mathrm{ml}$ for Type 2 matched controls and $9.6 \mu \mathrm{g} / \mathrm{ml}$ for non-diabetic controls. Mean difference for the LADA-type 2 comparison was calculated after data was log transformed and showed a difference of $1.58 \mu \mathrm{g} / \mathrm{ml}(95 \% \mathrm{Cl}: 1.28-1.95, \mathrm{p}=0.0001)$. There was no significant difference between LADA and non-diabetic controls $(p=0.54)$.

Conclusions: Adiponectin levels are higher among people with LADA compared to those with type 2 diabetes and are equivalent to levels seen in non-diabetic controls. This suggests that risk of complications in LADA, as with type 1 diabetes may be related more to glycaemic control rather than to factors of the metabolic syndrome.
\end{abstract}

\section{Background}

Adiponectin is a marker of insulin resistance, with lower levels being associated with reduced insulin sensitivity, less favourable lipid profiles and increased risk of developing cardiovascular disease in many studies [1-4]. However this may not be so clear cut as more recent studies in coronary patients have yielded contradictory results [5]. Furthermore, adiponectin levels are lower in people with type 2 diabetes and the metabolic syndrome [6]. However, adiponectin levels have been found to be elevated in people with a type 1 diabetes [7] and may be associated with increased onset of microalbuminuria [8]. Latent autoimmune diabetes in adults [LADA] is a slowly progressive type 1 diabetes [9-12] with features of both type 1 and type 2 diabetes. A person with LADA is not insulin dependent at diagnosis and in this way resembles type 2 diabetes. LADA can be distinguished from type 2 diabetes by antibody test such as a glutamic acid decarboxylase antibody (GADA) test. There is very limited information available regarding the risk of heart disease among people with LADA and existing data is

\footnotetext{
* Correspondence: s.brophy@swansea.ac.uk

${ }^{1}$ Senior Lecturer in Epidemiology and Public Health. College of Medicine, Swansea University. Swansea, SA2 8PP UK

Full list of author information is available at the end of the article
}

contradictory [13-15]. Adiponectin levels are a reflection of the amount of visceral fat or the obesity levels of the person. Thus, adiponectin levels may give an indication of the extent to which abdominal obesity may play a role in risk of complications for LADA patients. This study aims to examine Adiponectin levels in people with LADA compared to those with type 2 diabetes and compared to non-diabetic controls.

\section{Methods \\ Design}

Matched case control study with cases (LADA patients) matched with controls (type 2 diabetes and non-diabetic controls) for sex as adiponectin levels are higher in women compared to men [16]. The cases were matched one to one with a type 2 diabetes control and a nondiabetic control. Cases were not matched for BMI, as obesity was not believed to be a confounder but to be a causal factor [17].

\section{Patients}

1,630 patients over the age of 18 , with a diagnosis of type 2 diabetes within the previous 12 months (not requiring insulin at diagnosis) were tested for GADA within the Immunology Laboratory of the ABM University NHS 
Trust. Of these patients, 64 (3.9\%) who had GADA titres of 20 WHO units (27 Female, 37 Male) or more, were recorded as GADA positive and labelled as LADA cases. Those patients had a GADA test of 5 WHO units or less were recorded as GADA negative and labelled as type 2 control patients. Those with GADA titres between 5 and 20 WHO units were excluded from the study.

Sex matched controls $(n=64)$ were selected at random from the GADA negative type 2 patients. In addition, sex matched anonymised blood samples were obtained from people who did not have a diagnosis of diabetes on their medical record (non-diabetic controls $(\mathrm{n}=64))$ and had a blood test which had a negative result were selected from normal blood samples going through the Biochemistry Department of the ABM University NHS Trust.

\section{Setting}

GADA testing was conducted in May 2006 to Dec 2008. Patients were tested by their general practitioner (GP) at the same time as undergoing their first diabetes annual review (DAR) blood tests.

\section{Adiponection}

The concentration of plasma adiponectin was assayed using an ELISA-based Quantikine Human Acrp30 immunoassay kit (R\&D Systems, Minneapolis, Minnesota) according to the manufacturer's instructions. The assay measures total (low, middle and high molecular weight) adiponectin and employs a quantitative sandwich enzyme immunoassay technique to determine adiponectin concentrations. Standards over the range of $1-250 \mathrm{mg} / \mathrm{L}$ were prepared using recombinant human adiponectin. All plasma samples were diluted according to the manufacturer's instructions. The intra-and inter-assay coefficients of variation are $5.83 \%$ and $3.12 \%$ respectively.

\section{GADA antibody testing}

GADA were measured using an ELISA ( $65 \mathrm{kDa}$ antibody) from RSR Cardiff, UK [18] and analysed in the Department of Immunology at Singleton Hospital, Abertawe Bromorganwwg University NHS Trust. This ELISA kit achieved 98\% $(\mathrm{n}=100)$ specificity and $92 \%$
Table 1 Demographic characteristics

\begin{tabular}{llll}
\hline & LADA & $\begin{array}{l}\text { Type 2 } \\
\text { diabetes }\end{array}$ & $\begin{array}{l}\text { Mean difference } \\
(\mathbf{9 5 \%} \mathrm{Cl})\end{array}$ \\
\hline Age (years) & $49.6 \pm 15.3$ & $57.0 \pm 14.8$ & $7.4(4.9-9.8)$ \\
BMl $\left(\mathrm{kg} / \mathrm{m}^{2}\right)$ & $28.3 \pm 5.7$ & $31.3 \pm 6.4$ & $3.0(1.9-4.0)$ \\
\hline
\end{tabular}

( $\mathrm{n}=50)$ sensitivity in the Diabetes Antibody Standardization Programme (DASP) [19].

\section{Statistical analysis}

The Shapiro-Wilk test was used to test for normal distribution. The data were $\log$ transformed and matched pair T-tests were used to compare LADA patients with type 2 diabetic controls and with non-diabetic controls. SPSS version 13 was used for analysis.

Ethical approval was granted by the South West Wales REC in October 2008.

\section{Results}

The clinical characteristics and demographics of LADA patients and the non matched type 2 control patients are outlined in a previous study [20] (see table 1). However, as the non diabetic control group did not give informed consent we had very limited information regarding their clinical characteristics. When matched the average age of participants was 53 years (S.D. 15.6 yrs), 54 years (S.D. 20 yrs), and 54 years (S.D. 14.6 yrs) for the LADA, nondiabetic and type 2 diabetes controls respectively.

Patients with LADA (GAD antibody positive) had higher adiponectin levels than those with type 2 diabetes (GAD antibody negative) (Table 2). However, adiponectin levels for LADA patients did not differ from those found in non-diabetic controls.

\section{Discussion}

Patients with LADA have higher adiponectin levels than matched subjects with type 2 diabetes. This would suggest that abdominal obesity and visceral fat is less likely to be a risk factor or a causal factor for LADA. It is known that the BMI is lower among those with LADA compared with type 2 diabetes [20]. However, this study suggests that people with LADA are leaner for both abdominal/visceral fat as well as for subcutaneous/peripheral fat.

Table 2 Adiponection in LADA Cases and the Controls

\begin{tabular}{llllll}
\hline & $\begin{array}{l}\text { LADA } \\
\text { case } \\
(\mathbf{n}=64)\end{array}$ & $\begin{array}{l}\text { Type 2 control } \\
(\mathbf{n}=64)\end{array}$ & $\begin{array}{l}\text { Non-diabetic control } \\
(\mathbf{n}=\mathbf{6 4})\end{array}$ & $\begin{array}{l}\text { Mean difference LADA-Type } \\
\mathbf{2} \text { controls }\end{array}$ & $\begin{array}{l}\text { Mean difference LADA- } \\
\text { Nondiabetic controls }\end{array}$ \\
\hline $\begin{array}{l}\text { Adiponectin } \\
\text { (S.D) }\end{array}$ & $9.96(6.1)$ & $6.46(5.0)$ & $9.60(6.3)$ & $3.49(95 \% \mathrm{Cl}: 1.7-5.3)$ & $0.35(95 \% \mathrm{Cl}:-1.8$ to 2.5$)$ \\
$\begin{array}{l}\text { Log transformed } \\
\text { data }\end{array}$ & $\begin{array}{l}0.919 \\
(0.266)\end{array}$ & $0.717(0.27)$ & $0.892(0.29)$ & $0.20(0.11-0.29) p=0.0001$ & $0.027(-0.06$ to 0.11$) p=0.54$ \\
\hline
\end{tabular}

S.D-Standard Deviation. 


\section{Conclusions}

This study confirms findings from other previous research [21] that the metabolic syndrome may not be a characteristic of LADA. It is possible that glycaemic control may be more of a risk factor for complications in LADA in the same way as classical Type 1 diabetes [15]. A prospective study with baseline adiponectin measurements is required within a sample of subjects with LADA to examine this further.

\section{List of abbreviations}

LADA-latent autoimmune diabetes in adults, GADA-glutamic acid decarboxylase antibody, BMI-Body Mass Index.

\section{Acknowledgements}

The cost of the adiponectin tests were funded by a grant from the BUPA Foundation and the cost of the GAD antibody tests were funded by a grant from Novo Nordisk. The funders had no influence on the design, interpretation or reporting of this study.

\section{Author details}

${ }^{1}$ Senior Lecturer in Epidemiology and Public Health. College of Medicine, Swansea University. Swansea, SA2 8PP UK. ${ }^{2}$ College of Medicine, Swansea University, Swansea, SA2 8PP UK.

\section{Authors' contributions}

All authors contributed to designing the research question and to writing the manuscript. SB, HD and RW collected the data, laboratory analysis was performed by SP and JL. Statistical analysis was performed by SB.

\section{Competing interests}

The authors have no conflicts of interest to disclose.

Received: 19 August 2010 Accepted: 22 November 2010 Published: 22 November 2010

\section{References}

1. Trujillo ME, Scherer PE: Adiponectin-journey from an adipocyte secretory protein to biomarker of the metabolic syndrome. J Intern Med 2005, 257(2):167-75.

2. Hotta K, Funahashi T, Arita Y, Takahashi M, Matsuda M, Okamoto Y, Iwahashi H, Kuriyama H, Ouchi N, Maeda K, Nishida M, Kihara S, Sakai N, Nakajima T, Hasegawa K, Muraguchi M, Ohmoto Y, Nakamura T, Yamashita S, Hanafusa T, Matsuzawa Y: Plasma concentrations of a novel, adipose-specific protein, adiponectin, in type 2 diabetic patients. Arterioscler Thromb Vasc Biol 2000, 20(6):1595-9.

3. Kumada M, Kihara S, Sumitsuji S, Kawamoto T, Matsumoto S, Ouchi N, Arita Y, Okamoto Y, Shimomura I, Hiraoka H, Nakamura T, Funahashi T, Matsuzawa Y: Association of hypoadiponectinemia with coronary artery disease in men. Arterioscler Thromb Vasc Biol 2003, 23(1):85-9.

4. Shimabukuro M, Higa N, Asahi T, Oshiro Y, Takasu N, Tagawa T, Ueda S, Shimomura I, Funahashi T, Matsuzawa Y: Hypoadiponectinemia is closely linked to endothelial dysfunction in man. J Clin Endocrinol Metab 2003, 88(7):3236-40.

5. Antoniades C, Antonopoulos AS, Tousoulis D, Stefanadis C: Adiponectin: from obesity to cardiovascular disease. Obes Rev 2009, 10(3):269-79.

6. Yun JE, Sull JW, Lee HY, Park E, Kim S, Jo J, Lee SJ, Kim SY, Choi YJ, Jee SH, Huh KB: Serum adiponectin as a useful marker for metabolic syndrome in type 2 diabetic patients. Diabetes Metab Res Rev 2009.

7. Amin R, Frystyk J, Ong K, Dalton RN, Flyvbjerg A, Dunger DB: The development of microalbuminuria is associated with raised longitudinal adiponectin levels in female but not male adolescent patients with type 1 diabetes. Diabetologia 2008, 51(9):1707-13.

8. Leth $\mathrm{H}$, Andersen KK, Frystyk J, Tarnow L, Rossing P, Parving HH, Flyvbjerg A: Elevated levels of high-molecular-weight adiponectin in type 1 diabetes. J Clin Endocrinol Metab 2008, 93(8):3186-91.
9. Alberti KG, Zimmet PZ: Definition, diagnosis and classification of diabetes mellitus and its complications. Part 1: diagnosis and classification of diabetes mellitus provisional report of a WHO consultation. Diabet Med 1998, 15(7):539-53.

10. Appel SJ, Wadas TM, Rosenthal RS, Ovalle F: Latent autoimmune diabetes of adulthood (LADA): an often misdiagnosed type of diabetes mellitus. $J$ Am Acad Nurse Pract 2009, 21(3):156-9.

11. Pozzilli P, Di Mario U: Autoimmune diabetes not requiring insulin at diagnosis (latent autoimmune diabetes of the adult): definition, characterization, and potential prevention. Diabetes Care 2001, 24(8):1460-7.

12. Leslie RD, Kolb H, Schloot NC, Buzzetti R, Mauricio D, De Leiva A, Yderstraede K, Sarti C, Thivolet C, Hadden D, Hunter S, Schernthaner G, Scherbaum W, Williams R, Pozzilli P: Diabetes classification: grey zones, sound and smoke: Action LADA 1. Diabetes Metab Res Rev 2008, 24(7):511-9.

13. Myhill P, Davis WA, Bruce DG, Mackay IR, Zimmet P, Davis TM: Chronic complications and mortality in community-based patients with latent autoimmune diabetes in adults: the Fremantle Diabetes Study. Diabet Med 2008, 25(10):1245-50.

14. Szepietowska B, Szelachowska M, Gorska M, Jakubczyk D, Kinalska I: [Chronic complications in adult patients with newly diagnosed diabetes mellitus in relation to the presence of humoral autoimmune markers against pancreatic islet cells]. Pol Arch Med Wewn 2004, 111(5):563-9.

15. Isomaa B, Almgren P, Henricsson M, Taskinen MR, Tuomi T, Groop L, Sarelin L: Chronic complications in patients with slowly progressing autoimmune type 1 diabetes (LADA). Diabetes Care 1999, 22(8):1347-53.

16. Koerner A, Kratzsch J, Kiess W: Adipocytokines: leptin-the classical, resistin-the controversical, adiponectin-the promising, and more to come. Best Pract Res Clin Endocrinol Metab 2005, 19(4):525-46.

17. Bhopal R: Concepts of Epidemiology: an integrated introduction to the ideas, theories, principles and methods of epidemiology. New York: Oxford University Press; 2003.

18. Glutamic Acid Decarboxylase (GAD) Autoantibody ELISA kit from RSRinstructions for use. 2007 [http://www.rsrltd.com], [cited 2009 13/03/09].

19. Bingley PJ, Bonifacio E, Mueller PW: Diabetes Antibody Standardization Program: first assay proficiency evaluation. Diabetes 2003, 52(5):1128-36.

20. Davies $H$, Brophy S, Fielding A, Bingley P, Chandler M, Hilldrup I, Brooks C, Williams R: Latent autoimmune diabetes in adults (LADA) in South Wales: incidence and characterization. Diabet Med 2008, 25(11):1354-7.

21. Hawa MI, Thivolet C, Mauricio D, Alemanno I, Cipponeri E, Collier D, Hunter S, Buzzetti R, de Leiva A, Pozzilli P, Leslie RD: Metabolic syndrome and autoimmune diabetes: action LADA 3. Diabetes Care 2009, 32(1):160-4.

doi:10.1186/1756-0500-3-317

Cite this article as: Brophy et al:: Adiponectin levels in people with Latent Autoimmune Diabetes-a case control study. BMC Research Notes 2010 3:317

\section{Submit your next manuscript to BioMed Central and take full advantage of:}

- Convenient online submission

- Thorough peer review

- No space constraints or color figure charges

- Immediate publication on acceptance

- Inclusion in PubMed, CAS, Scopus and Google Scholar

- Research which is freely available for redistribution 